\title{
Qualitative Multi-Criteria Evaluation OF ENERGY CROPS
}

\author{
Vindis, P.; STAJNKO, D.; BeRK, P. \& LAKOTA, M.
}

Abstract: The aim of the paper is to present the system for multi-criteria evaluation of energy crops for biogas production. Firstly, the deterministic simulation system consists of deterministic production simulation models was build. Simulation model results were further evaluated using a qualitative multi-attribute modelling methodology DEX (supported by the software tool DEX-i). The analysis showed that by using current model the most relevant alternative used for energy crop for biogas production is maize. The maize results in the best DEX-i multicriteria evaluation appropriate. The best alternative for maize is sorghum with multicriteria evaluation less appropriate.

Key words: multicriteria decision analysis, simulation model, energy crops, DEX-i
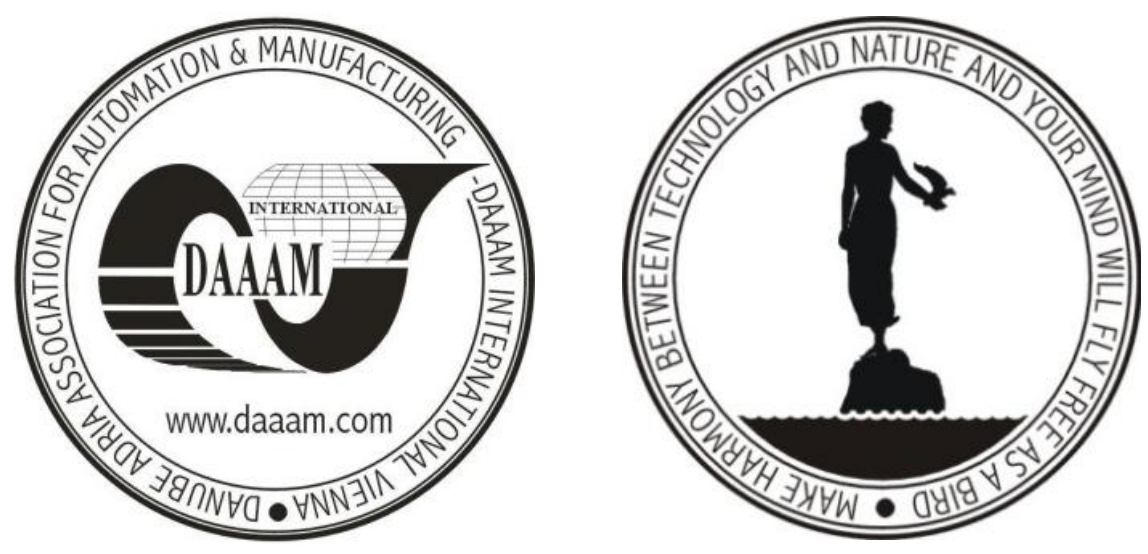

Authors' data:Dr. Vindis, P[eter]; Assoc. Prof. Stajnko, D[enis], Bs. Elect. Eng. Berk, P[eter]; Assoc. Prof. Lakota, M[iran], University of Maribor, Faculty of Agriculture and Life Sciences, Pivola 10, SI-2311, Hoce, Slovenia, peter.vindis@unimb.si,denis.stajnko@uni-mb.si, peter.berk@uni-mb.si,miran.lakota@uni-mb.si.

This Publication has to be referred as: Vindis, P[eter]; Stajnko, D[enis]; Berk, P[eter] \& Lakota, M[iran] (2010). Qualitative Multi-Criteria Evaluation of Energy Crops, Chapter 11 in DAAAM International Scientific Book 2010, pp. 099-106, B. Katalinic (Ed.), Published by DAAAM International, ISBN 978-3-901509-74-2, ISSN 1726-9687, Vienna, Austria

DOI: $10.2507 /$ daaam.scibook.2010.11 
Vindis, P.; Stajnko, D.; Berk, P. \& Lakota, M.: Qualitative Multi-Criteria Evaluatio...

\section{Introduction}

The $21^{\text {st }}$ century faces the problem of growing energy consumption and diminishing supplies of fossile fuels, which has led to researches of the use of renewable energy sources and, consequently, the development of new technological processes of energy production. One of the most efficient energy sources is the biogas produced from green energy crops and organic waste matters. The biogas is formed during anaerobic fermentation of organic matters such as: farmyard manure, liquid manure, energy crops, organic waste materials, slaughter-house waste etc. (Navickas, 2007). Economic efficiency of anaerobic digestion depends on the investment costs, on the costs for operating the biogas plant and on the optimum methane production (Weiland, 2003).

From technological aspect the most suitable energy crops grown in the temperate conditions are the grasses, maize, sorghum and legumes such as white clover, vetches and lupine (Lehtomäki, 2006). Among the alternative energy crops the literature mentions the forage kale, Jerusalem artichoke, Miscanthus sp. and some weeds (Callaghan et al., 1985).

An important issue is evaluating the suitability of energy crops for biogas with respect to various criteria on the basis of different analyses (amount of produced biogas, biomass yield) and the association in a single multi-criteria estimate. In such cases, the multi-criteria analyses were used by different authors (Rozman et al., 2006; Pazek el. al., 2006). In the last few decades, the agricultural decision makers have gotten accustomed to the use of computers and consequently to the implementation of different complex computer models for solution of various planning problems. This includes decision problems and agricultural project solutions, which have long been predominated by different types of simulation models (Rozman et al., 2002) and cost benefit analysis (CBA) as presented by (Pažek et al., 2004).

The basic problem of the research is to develop a system to support decision making in the selection of appropriate energy crop, with the combination of the technological-economic simulation model (model calculations) and multi-criteria decision analysis. This paper presents the application of the simulation model for cost analysis of biogas, electricity and heat production from various energy crops in combination with multi criteria decision models. The simulation results are additionally evaluated with multi criteria decision models based on DEX-i expert system.

\section{Methodology}

Using technological-economic simulation modelling one can obtain information about the system itself and its responses to different model input parameters. The relationships between system elements (in this case input material, human labor) are expressed with a series of technological equations that are used for calculation of input usage and outputs produced. For financial and technological analysis of energy crops for biogas production the computer simulation model was developed. There are three basic sub-models: 
- The sub model of energy crop production by the farmer;

- The sub model of biogas production from energy crops;

- The sub model of electricity and heat production from biogas produced from energy crops.

The developed model enables calculation of the most important economic parameters such as break-even price, coefficient of profitability and financial result. The simulation model output data represent some of the input parameter of analyzed energy crops in multi-criteria decision analysis. The structure of the assessment procedure is shown in Figure 1.

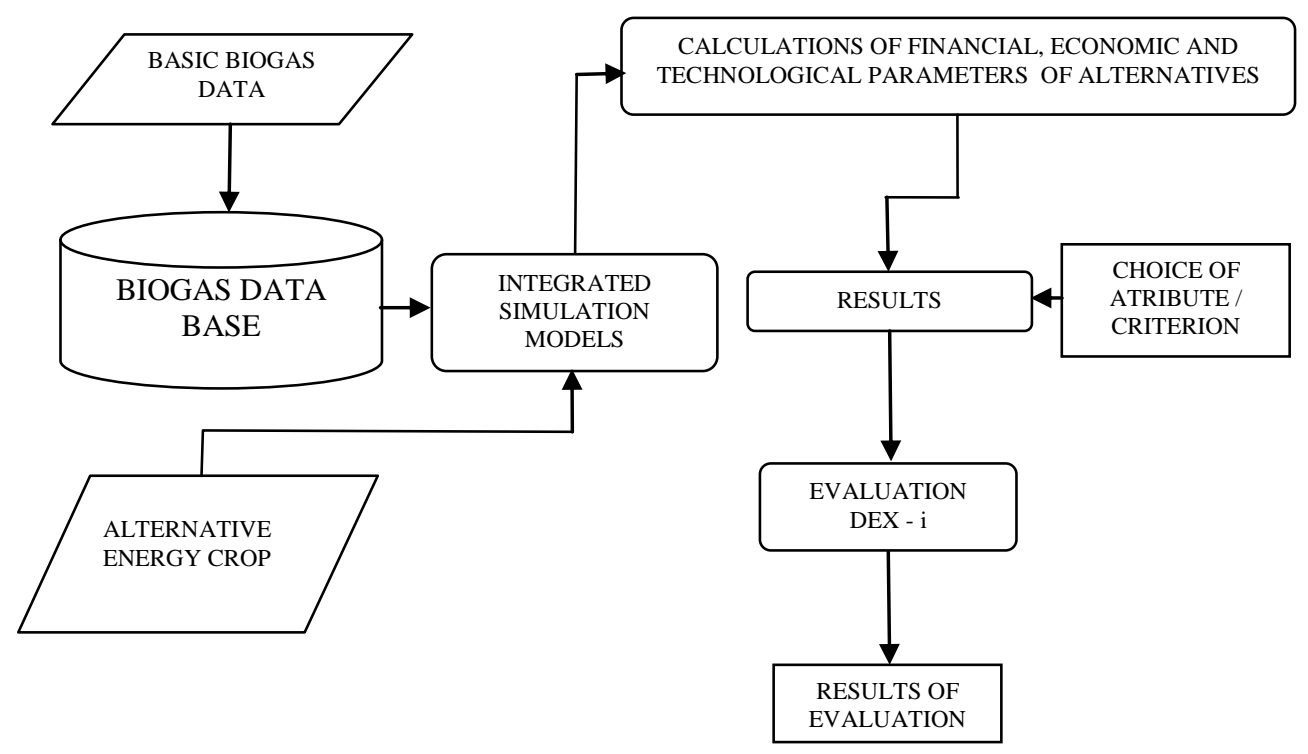

Fig. 1. The structure of deterministic simulation model BIOGAS

\subsection{The computer prototype of simulation model BIOGAS}

The computer prototype of simulation model BIOGAS was developed in order to simplify the work, calculations and to find alternative solution as soon as possible. The use of appropriate computer programs enables quickly and easily making of calculations.

To develop the model we use the software package MS Excel 2003, combined with the programming language VBA ("Visual Basic for Applications", VBA). Based on the individual production models, the computer calculates the technological parameters of production, which are the basis for the technological map, with calculations of the total costs. A single model collects data and calculate a certain economic parameters (breakeven price of production of energy crops, breakeven price of production of electricity and heat energy, financial results, the coefficient of economy, etc..) on various input parameters (different inputs, prices, different crop and biogas yields,...).

Figure 3 shows basic menu of three main sub models of the simulation model BIOGAS. 
Vindis, P.; Stajnko, D.; Berk, P. \& Lakota, M.: Qualitative Multi-Criteria Evaluatio...

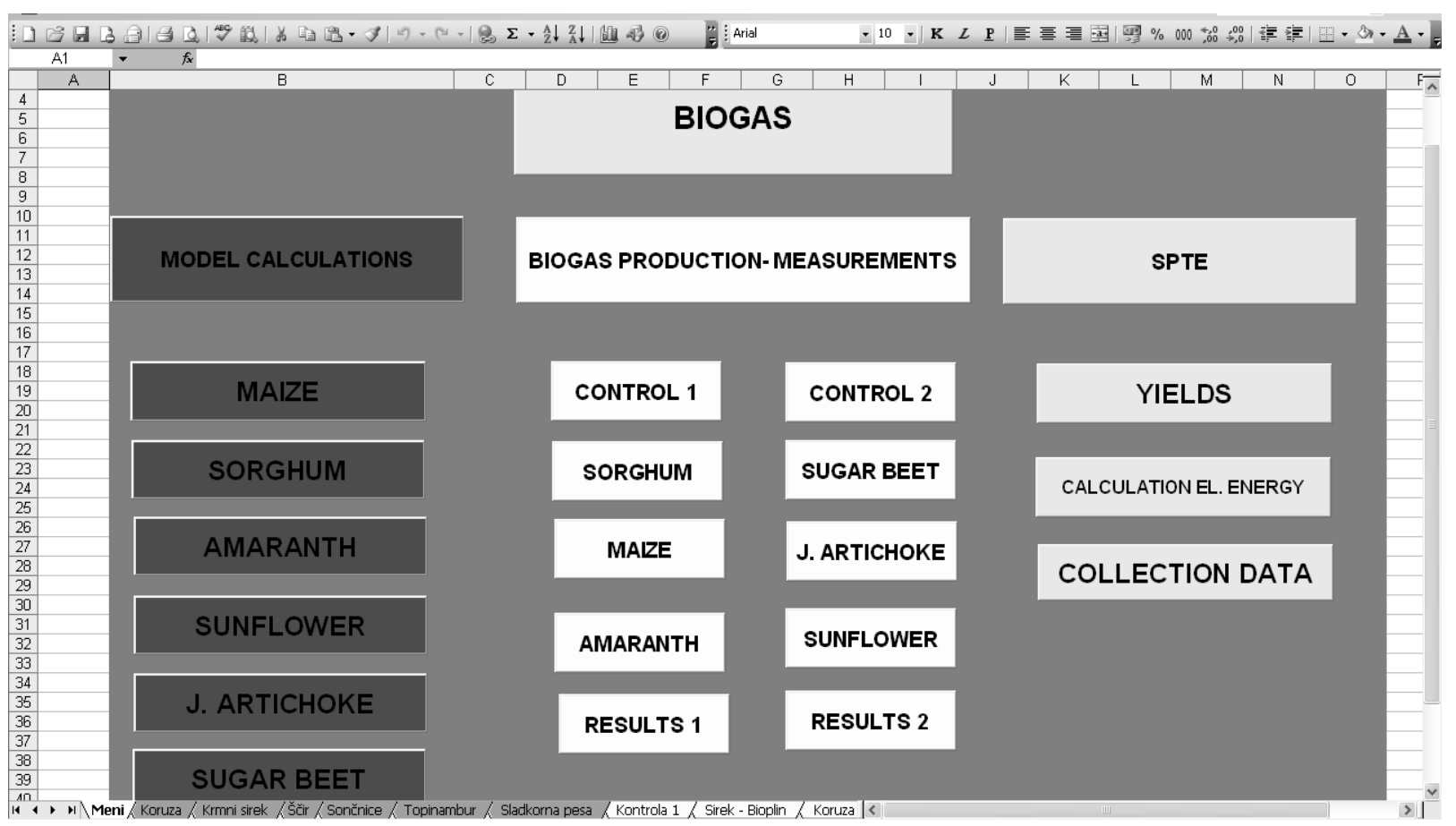

Fig. 3. Basic menu of three main sub models of the simulation model BIOGAS

Computer based simulation model generates a database of all productions and measurements in the worksheet collection data and collects the estimated parameters for all energy crops from each sub model. The collected data are then through a series of programming commands transferred into the table where the economic indicators are calculated for each investment in the processing of energy crops into biogas. Sub model biogas production is based on data obtained by laboratory experiments of anaerobic digestion and is related with other models.

\subsection{The DEX-i assessment}

The energy crops are further evaluated with multi criteria decision model. Hierarchical multi-criteria decision models are a general decision support methodology aimed at the classification or evaluation of options that occur in decision-making processes. Decision models are typically developed through the decomposition of complex decision problems into smaller and less complex subproblems; the result of such decomposition is a hierarchical structure that consists of attributes and utility functions.

The variants are decomposed into specific parameters (criteria, attribute and objective) and evaluated separately for each single parameter. The final variant evolution is provided with the combined proceeding. The provided value presents the portfolio for selection of the most suitable variant (Bohanec \& Rajkovic, 1995). For the assessment of simulated alternatives DEX-i methodology has been applied. DEX is a methodology for qualitative multi-criteria decision modelling and support (Bohanec \& Rajkovic, 1990). DEX combines conventional multi-criteria decisionmaking with some elements of Expert Systems and Machine Learning. The distinguishing characteristic of DEX is its capability to deal with qualitative variables. Instead of numerical variables, which typically constitute traditional quantitative models, DEX uses qualitative variables whose values are usually 
represented by words rather than numbers, such as "low," "appropriate," and "unacceptable." To represent and evaluate decision alternatives, DEX uses 'if-then' decision rules. The DEX method is implemented with the software program DEX-i.

The numerical attributes for the DEX - $\mathrm{i}$ analysis were obtained by simulation using the simulation model, while the non numerical attributes were estimated based on different data sources. The following qualitative scales were used for non numerical sub-attributes (Table 1).

\begin{tabular}{|l|l|}
\hline The use of fertilizers (nitrogen) & Qualitative Values \\
\hline$>195$ & high \\
\hline $131-194$ & medium \\
\hline $0-130$ & low \\
\hline BEP farmer $(\mathrm{Eu} / \mathrm{kg})$ & \\
\hline$<0,08$ & high \\
\hline $0,035-0,08$ & medium \\
\hline$>0,035$ & low \\
\hline BEP el. energy $(\mathrm{Eu} / \mathrm{kWh})$ & \\
\hline$<0,4$ & high \\
\hline $0,2-0,4$ & medium \\
\hline$>0,2$ & low \\
\hline BEP heat energy $(\mathrm{Eu} / \mathrm{kWh})$ & \\
\hline$<0,2$ & high \\
\hline $0,11-0,2$ & medium \\
\hline$>0,1$ & low \\
\hline $\mathrm{C} / \mathrm{N}$ ratio & \\
\hline $15-30 / 1$ & optimum \\
\hline$><15-30 / 1$ & less appropriate \\
\hline
\end{tabular}

Tab. 1. Categorization table for numerically measured attributes

After each attribute has been assigned with qualitative value, the utility functions are defined. The utility function is conducted for each level in the hierarchy and the decision rules are presented in complex form. Table 2 shows qualitative scales for non-numerical attributes. Finally, attribute values for each alternative are put into DEX-i evaluation table and the analysis is ultimately conducted.

\begin{tabular}{|l|l|}
\hline Hailstone risk & high; medium; low \\
\hline Resistance to drought & resistant; partially resistant; un-resistant \\
\hline Crop rotation & monoculture; two years; three years \\
\hline The use of pesticides & high; medium; non \\
\hline Insistence of the production & high; medium; low \\
\hline suitability of crop biogas production & appropriate; less appropriate; inappropriate \\
\hline suitability of plant - digestor & appropriate; less appropriate; inappropriate \\
\hline
\end{tabular}

Tab. 2. Qualitative scales for non-numerical attributes 
Vindis, P.; Stajnko, D.; Berk, P. \& Lakota, M.: Qualitative Multi-Criteria Evaluatio...

\section{Results and discussion}

By using technological-economic simulation model BIOGAS individual alternatives - energy crops were simulated. Using the developed simulation system the technological - economic parameters of production and processing energy crops into biogas were estimated. Six energy crops were analyzed:

- Alternative 1: Maize (Zea mays L.) sort PR 34N43 (FAO 580)

- Alternative 2: Sorghum (Sorghum L.) sort Autan

- Alternative 3: Amaranth (Amaranthus sp. L.) sort Acruentus G6

- Alternative 4: Sunflower (Helianthus annuus L.) sort PR64A43

- Alternative 5: Jerusalem artichoke (Helianthus tuberosus L.)

- Alternative 6: Sugar beet (Beta vulgaris sp. L) sort Remos

In the first phase for every analyzed alternative the costs of energy crop production are calculated using the simulation model. In the second phase, the data from the experiment (produced biogas) were calculated into the electricity and heat yield. The results of developed integrated deterministic simulation model depend on quality of incoming data of the model. Table 3 shows the results of the simulation model for the individual alternative.

\begin{tabular}{|l|c|c|c|c|c|c|c|c|}
\hline & $\begin{array}{c}\text { Biogas } \\
{[\mathbf{N I} / \mathbf{k g V S}]^{\mathbf{a}}}\end{array}$ & $\begin{array}{c}\text { Biogas } \\
{\left[\mathbf{N m}^{\mathbf{3} / \mathbf{h a}}\right]^{\mathbf{b}}}\end{array}$ & $\begin{array}{c}\mathbf{E l} \text { energy } \\
{[\mathbf{k W h} / \mathbf{h a}]}\end{array}$ & $\begin{array}{c}\text { Heat } \\
\mathbf{e n e r g y} \\
{[\mathbf{k W h} / \mathbf{h a}]}\end{array}$ & $\begin{array}{c}\mathbf{B E P}^{\mathbf{c}} \\
\mathbf{f a r m e r} \\
{[\mathbf{\epsilon} / \mathbf{k g}]}\end{array}$ & $\begin{array}{c}\mathbf{B E P}^{\mathbf{c}} \mathbf{\text { el. }} \\
\mathbf{e n e r g y} \\
{[\mathbf{\epsilon} / \mathbf{k W h}]}\end{array}$ & $\begin{array}{c}\mathbf{B E P}^{\mathbf{c}} \mathbf{h} . \\
\mathbf{e n e r g y} \\
{[\mathbf{\epsilon} / \mathbf{k W h}]}\end{array}$ & $\begin{array}{c}\mathbf{C} / \mathbf{N} \\
\mathbf{r a t i o}\end{array}$ \\
\hline Maize & 576 & 10332.5 & 20665 & 37197 & 0.026 & 0.18 & 0,10 & $1: 24$ \\
\hline Sorghum & 509 & 7783.5 & 15567 & 28020 & 0.029 & 0.23 & 0,13 & $1: 30$ \\
\hline Amaranth & 421 & 3641.4 & 7283 & 13109 & 0.782 & 0.51 & 0,28 & $1: 14$ \\
\hline Sunflower & 495 & 5749.6 & 11499 & 20698 & 0.329 & 0.28 & 0,16 & $1: 40$ \\
\hline $\begin{array}{l}\text { Jerusalem } \\
\text { artichoke }\end{array}$ & 463 & 5104.8 & 10210 & 18377 & 0.079 & 0.40 & 0,22 & $1: 42$ \\
\hline $\begin{array}{l}\text { Sugar } \\
\text { beet }\end{array}$ & 649 & 5823.3 & 11647 & 20964 & 0.038 & 0.34 & 0,19 & $1: 33$ \\
\hline
\end{tabular}

${ }^{a}$ norm litre per kg of volatile solids (273 K, 1.013 bar)

${ }^{\mathrm{b}}$ norm $\mathrm{m}^{3}$ per hectare

${ }^{\mathrm{c}}$ breakeven price

Tab. 3. The results of biogas production measurements and simulation model for individual energy crop

The simulation results were further evaluated with multi criteria decision model DEX-i. Since the main results from the simulation model are numerical (break even prices, $\mathrm{C} / \mathrm{N}$ ratio), the qualitative values must be assigned to each quantitative parameter in order to enable further analysis in DEX-i decision model. This is conducted with classification algorithm based on classification intervals.

The DEX-i evaluation of alternatives (energy crops) with importance weights of aggregate attributes is shown in table 4. 


\begin{tabular}{|c|c|c|c|c|c|c|}
\hline Attribute & Sunflower & J. artichoke & Sorghum & Sugar beet & Amaranth & Maize \\
\hline Assessment & $\begin{array}{c}\text { less } \\
\text { appropriate }\end{array}$ & inappropriate & less appropriate & $\begin{array}{c}\text { less } \\
\text { appropriate }\end{array}$ & inappropriate & appropriate \\
\hline $\begin{array}{l}\text { Economic } \\
\text { criteria*W=55\% }\end{array}$ & good & bad & good & good & bad & excellent \\
\hline BEP farmer & high & medium & low & medium & high & low \\
\hline BEP el. energy & medium & high & medium & medium & high & low \\
\hline BEP heat energy & medium & high & medium & medium & high & low \\
\hline $\begin{array}{l}\text { Technological } \\
\text { criteria } * \mathrm{~W}=29 \%\end{array}$ & bad & bad & good & bad & bad & good \\
\hline $\begin{array}{l}\text { Production } \\
\text { technology - } \\
\text { biogas }\end{array}$ & demanding & demanding & non demanding & demanding & non demanding & non demanding \\
\hline $\begin{array}{l}\text { Property of crop- } \\
\text { biogas }\end{array}$ & $\begin{array}{c}\text { less } \\
\text { appropriate }\end{array}$ & less appropriate & appropriate & inappropriate & less appropriate & appropriate \\
\hline $\begin{array}{l}\text { Property of crop- } \\
\text { digestor }\end{array}$ & $\begin{array}{c}\text { less } \\
\text { appropriate }\end{array}$ & inappropriate & appropriate & inappropriate & appropriate & appropriate \\
\hline $\mathrm{C} / \mathrm{N}$ ratio & $\begin{array}{c}\text { less } \\
\text { appropriate }\end{array}$ & less appropriate & optimum & $\begin{array}{c}\text { less } \\
\text { appropriate }\end{array}$ & optimum & optimum \\
\hline $\begin{array}{l}\text { Production } \\
\text { technology-plants }\end{array}$ & demanding & $\begin{array}{c}\text { middle } \\
\text { demanding }\end{array}$ & $\begin{array}{c}\text { middle } \\
\text { demanding }\end{array}$ & demanding & $\begin{array}{c}\text { middle } \\
\text { demanding }\end{array}$ & $\begin{array}{c}\text { middle } \\
\text { demanding }\end{array}$ \\
\hline $\begin{array}{l}\text { Difficulty of } \\
\text { production }\end{array}$ & medium & low & medium & high & low & medium \\
\hline Crop rotation & three years & three years & two years & three years & two years & two years \\
\hline $\begin{array}{l}\text { Production } \\
\text { risk }\end{array}$ & high & medium & medium & medium & medium & medium \\
\hline Hailstone risk & high & medium & high & low & medium & high \\
\hline $\begin{array}{l}\text { Resistance to } \\
\text { drought }\end{array}$ & un-resistant & $\begin{array}{l}\text { partially } \\
\text { resistant }\end{array}$ & resistant & un-resistant & $\begin{array}{l}\text { partially } \\
\text { resistant }\end{array}$ & $\begin{array}{l}\text { partially } \\
\text { resistant }\end{array}$ \\
\hline $\begin{array}{l}\text { Environment } \\
\text { criteria*W=29\% }\end{array}$ & good & good & bad & bad & bad & neutral \\
\hline $\begin{array}{l}\text { The use of } \\
\text { fertilizers } \\
\text { (nitrogen) }\end{array}$ & low & low & high & high & high & medium \\
\hline $\begin{array}{l}\text { The use of } \\
\text { pesticides }\end{array}$ & medium & non & medium & high & medium & medium \\
\hline Ranking & 2 & 3 & 2 & 2 & 3 & 1 \\
\hline
\end{tabular}

Tab.4: DEX-i project evaluation of alternatives with importance weights of aggregate attributes

The DEX-i evaluation of alternatives result in the ranking of alternatives: maize, sorghum, sunflower, sugar beet, amaranth and Jerusalem artichoke. Using DEX-i expert system it can be defined which combination of attribute values is not acceptable for the decision maker. Thus, the DEX-i assessment can be used for exclusion of unacceptable alternatives, but the shortcoming of DEX - $\mathrm{i}$ is its inability to separate between alternatives with the same qualitative evaluation.

\section{Conclusion}

In this paper, an attempt is made to employ multi-criteria analysis to assess suitability of energy crops for processing into biogas.

The integrated computer supported simulation model combined with multi criteria decision analysis presents a suitable methodology tool for decision support system on farms and biogas plants. The system takes into consideration different independent criteria and enables ranking of alternatives (energy crops for biogas production). The use of multi criteria decision approaches can bring additional information into the decision making framework (for instance the unacceptable alternatives can be excluded with the use of the DEX-i model). 
Vindis, P.; Stajnko, D.; Berk, P. \& Lakota, M.: Qualitative Multi-Criteria Evaluatio...

In the presented paper DEX-i method favoured the maize, which got the highest DEX-i evaluation. The maize is followed by sorghum and can be used as an alternative for maize (crop rotation, drought etc.). The next alternatives are sunflower, sugar beet, amaranth, while Jerusalem artichoke got the worst evaluation. The application of the proposed decision support system (combination of simulation model and DEX-i methodology) would increase the accuracy of information needed for developing farm and biogas plant plans and, in addition, it would help preventing many inappropriate decision being made on farms and biogas plants.

\section{References}

Bohanec, M.\& Rajkovic, V. (1995). Multi criteria decision models. Organization, Vol. 7, pp. 27,ISSN 1318-5454

Bohanec, M.\&Rajkovic, V. (1990). DEX: An expert system shell for decision support. Sistemica, Vol. 1, pp. 145-157, ISSN 1014-935X

Callaghan, T.V.; Lawson, G.J.\&Scott, R. (1985). The potential of natural vegetation as a source of biomass energy. In: Palz, W., Coombs, J., Hall, D.O. (eds), Energy from biomass,ISBN: 978-0-85334-396-7, pp. 109-116

Lehtomäki, A. (2006). Biogas Production from Energy Crops and Crop Residues. Faculty of Mathematics and Science of the University of Jyväskylä, ISBN: 951-39-2559-5, Jyväskylä

Navickas, K. (2007). Biogas for farming, energy conversion and environment protection. International symposium Biogas, technology and environment. University of Maribor, Faculty of Agriculture,pp. 25-29, ISSN 1822-8801

Pazek, K.; Rozman, C.; Par, V.\& Turk J. (2004). Finacial analysis of investment in food processing at Slovenian organic farms. V: 39. Croatian Agriculture Scientific Conference with international participation, Opatija 17.-20. February 2004. Zagreb: Faculty of Agriculture, University of Zagreb, Croatia,ISBN 9536135-40-X,pp. 95-96

Pazek, K.; Rozman, C.; Borec, A.; Turk, J.; Majkovic, D.; Bavec, M.\& Bavec, F. (2006). The Multi criteria models for decision support on organic farms. Biological Agriculture and Horticulture, Vol. 24, No. 1, pp. 73-89, ISSN01448765

Rozman, C.; Tojnko, S.; Turk, J.; Par, V.\& Pavlovic, M. (2002). Die Anwendung eines Computersimulationsmodells zur Optimierung der Erweiterung einer Apfelplantage unter den Bedingungen der Republik Slowenien. Berichte über Landwirtschaft, Vol. 80, No. 4, ISSN0005-9080, pp. 632-642

Rozman, C.; Pazek, K.; Bavec, M.; Bavec, F.; Turk, J. \& Majkovic, D. (2006). The Multi-criteria Analysis of Spelt Food Processing Alternatives on Small Organic Farms. Journal of Sustainable Agriculture, Vol. 28, No. 2, pp. 159179,ISSN1044-0046

Weiland, P. (2003). Production and energetic use of biogas from energy crops and wastes in Germany. Applied Biochemistry and Biotechnology, Vol. 109, pp. 263-274, ISSN 0273-2289 